\title{
Mutual learning in conservation of biodiversity in China and South Africa - The role of national parks
}

\author{
By Meryl Burgess \\ Research Analyst at the Centre for Chinese Studies, Stellenbosch University
}

This is an excerpt from a larger work that has recently been published as a CCS Discussion Paper. You can access the full paper on the CCS website.

\section{Introduction}

The increase in depletion and extinction of the world's biodiversity has led to a greater interest from the global community to protect the environment and safeguard natural habitats and thousands of species. In developing countries like China and South Africa, factors like the growth and development of urban and rural spaces - with negative effects of industrialisation on the environment - as well as high population growth have added extra pressures to both countries' biodiversity and natural environments. Consequently, protected areas and specifically national parks have become increasingly important for conservation purposes. Beyond the conservation value of national parks, they are, however, also a place for activities such as education, tourism and relaxation.

National parks have a crucial role in the protected areas system in the world, as they provide important environmental protection services for the natural growth and life of ecological processes and habitats. For this reason, this study focused on national parks as protected areas in China and South Africa, their roles in biodiversity conservation, and the implementation of regulation in light of current challenges as well as the special case of tourism.

Regulation and management of parks are critical as parks need to uphold the laws and policy on biodiversity conservation and environmental protection. Most national parks, like other protected areas such as nature reserves and national heritage sites, fall within the laws and regulations of the state. They are important to regulate as these areas are essential for the conservation of a country's biodiversity. Moreover, laws and regulation on biodiversity conservation ensure that the proper management of the parks are ensured. This paper looked at where China could learn from South Africa as well as vice versa in terms of protected areas and dealing with current challenges.

1 National parks have a crucial role in the protected areas system in the world, as they provide important environmental protection services for the natural growth and life of ecological processes and habitats.

\section{China, threats to biodiversity and protected areas}

China is one of the world's richest and biologically most diverse countries, China's biodiversity accounts for an estimated 60 to $80 \%$ of all life on earth (Williams et al. 2001 quoted in Jordan, 2010). Due to the rapid development path of China in recent decades, much of the country's biodiversity and natural habitats have been destroyed. Harkness notes that "unprecedented economic growth has entailed large increases in the absolute demand for natural resources of all kinds over the past 
two decades" such as the rapid consumption of timber in the early reform period which led to depletion of many forest areas (1998: 914). Moreover, industrialisation, (including some agriculture sectors), further urbanisation caused by a migrating rural population, increasing consumption levels, accelerated extraction of minerals and ores, and growing air and car transportation have resulted in increases in resource use and higher pollution levels (Mol and Carter, 2007: 2), causing further harm to biodiversity.

According to Jordan (2010), the threat of biodiversity loss in plant species is particularly troublesome as a number of mammals, birds, invertebrates, and other plants depend on a narrow range of plants for their primary nutrition and other needs. A well-known native mammal, the Panda and other mammals in China are threatened by development and encroachment on their natural habitats, cutting off access to important migratory routes for feeding and breeding, and destroying necessary species and resources for life (Jordan, 2010: 44). Development and pollution has threatened their native habitats and thus endangered their movement or need to live in their natural environment. The conversion of natural habitats such as forests or grasslands to farm fields and human settlements has increased the loss of biodiversity (Harkness, 1998). Agriculture has been on the increase in order to sustain the populous country, leading to more pressure on the country's natural habitats. Maintaining a certain balance is necessary, however, not only for the sake of protecting beautiful landscape. Humans are dependent on a diverse range of plant life to sustain agriculture needs as well as the landscape remaining stable. Consequently, there is a need to protect the country's natural states. China has begun to address these challenges, with the increase in the establishment of protected areas as well as a National Biodiversity Conservation Strategy and Action Plan.

\section{One of the most important types of protected area today for conservation and recreation are national parks. \\ $\nabla 7$}

One of the most important types of protected area today for conservation and recreation are national parks. The International Union for the Conservation of Nature's (IUCN) category system for protected areas, lists national parks under Category II and describes national parks as "protected areas managed mainly for ecosystem protection and recreation" (Eagles and McCool, 2002: 19). The primary objective of national parks is "to protect natural biodiversity along with underlying ecological structure and supporting environmental processes, and to promote education and recreation" (Dudley, 2008: 16). It is important to note that recreation is mentioned but clearly as secondary to protecting biodiversity.

In China, the national park system is still in an early developing phase. There have been initiatives undertaken for ecological conservation via protected areas, one of the most concrete actions being the establishment of nature reserves, forest reserves, parks and other protected areas (McBeath and McBeath, 2006). According to Yuan et al (2008), 2,395 nature reserves were established as of 2006, accounting for $15-16 \%$ of Chinese territory. In this way, $85 \%$ of China's terrestrial ecosystems, $85 \%$ of its wild animal populations, and $65 \%$ of the country's wild vegetation communities are represented under the net of protected areas (SEPA, 2007).

Within its conservation system, national parks following international norms are only a recent development in China. In the literature found on biodiversity conservation and protected areas in China, we find different names and definitions for national parks. China has an older nature reserves system, hence all of the regulation on protected 
areas in China refers to nature reserves, forest parks and scenic landscapes. There are also debates regarding the first national park established in China. According to some authors and US-based "The Nature Conservancy" (TNC), the very first national park that followed IUCN standards established in China was the Pudacuo National Park in Yunnan province in 2005. However, confusion prevails on the status of protected areas and in how far international standards are applied. According to other sources, the first national park developed was the Yang Wang He National Park in Heilongjian Province (Anonymous, 2008). This park was the first official park named by the Ministry of Environmental Protection and National Tourism Administration in 2008 (Anonymous, 2008). There have been no national regulations developed for national parks in China. Yet, draft regulation has been developed for the pilot national parks projects in Yunnan province according to TNC staff (Niu, 2011).

China's park system is said to have been modelled on the US park system (Fritz, 2009). Direct interaction can especially be seen with the role of the TNC in the creation of the national park system in the Yunnan province (Zinda, 2011). TNC is said to have introduced the national park system to China as part of a partnership with the Chinese government (Haomin, 2011). According to Zinda (2011: 4) TNC played an influential role in promoting new conservation practices in Yunnan, China, starting in 1998. "The campaign to develop national parks in Yunnan arose from discontent among both conservationists and government authorities with China's dominant protected-area models, scenic areas and nature reserves" (Zinda, 2011). Furthermore, in practice, there were many limitations in the regulation of nature reserves on funding and the profitable economic activity disinclined local authorities to undertake effective implementation according to Zinda (2011). Also, in contrast, scenic areas were perceived to allow profitable tourism operations but had a weak conservation mandate (Zinda, 2011: 5). Thus a new system of national parks was necessary where these issues could be addressed under one protected area model.

II The campaign to develop national parks in Yunnan arose from discontent among both conservationists and government authorities with China's dominant protected-area models, scenic areas and nature reserves

\section{Mutual learning China-Africa?}

Interesting in the China-Africa dynamics, and as a change from the often heard discussion on learning from the Chinese model, the mutual learning with regard to national parks can be China learning from Africa. In comparison to the Chinese protected areas, South Africa has an old and established system of protected areas including nature and wildlife (game) reserves, many of them private; botanical gardens (such as Kirstenbosch Botanical gardens in Cape Town); as well as many national parks. Protected areas in South Africa were ultimately established for the protection of the rich biodiversity that the country holds as well as for recreation purpose. South Africa has a well-established national park system, with the very first national park (Kruger National Park) established in 1898. SANParks manages 54\% of South Africa's formal protected area network and is currently responsible for 22 national parks (SANParks, 2010: 5). South African national parks protects 4.15 million hectares -4 million ha on land and 150000 ha at sea (SANParks, 2010: 6).

Beyond national parks - and as an interesting additional characteristic - there are also contractual national parks in South Africa, established on land owned either by 
the state or a group of private individuals. Central to the idea of a contractual national park is the drawing up of a joint management agreement in which the rights and responsibilities of the landowners and the conservation authority that manages the land are laid out. Contractual national parks provide a framework through which social development, and economic objectives can be met without alienating local people, whilst conservation objectives can also be met without heavy investment in land purchase (de Villiers 1999a; Robinson 1994 quoted in Reid, et al. 2004: 377).

And, as a feature known across Africa, but presumably not in China, South Africa also has a number of transfrontier parks or transfrontier conservation areas. A transfrontier park is established where authorities are responsible for areas in which the primary focus is wildlife conservation, and which border each other across international boundaries. Those authorities then formally agree to manage those areas as one integrated unit according to a streamlined management plan. These authorities also undertake to remove all human barriers within the Transfrontier Park so that animals can roam freely (DEA, 2012). Slightly different, a transfrontier conservation area usually refers to a cross-border region where the different component areas have different forms of conservation status, such as Private Game Reserves, communal natural resource management areas, and even hunting concession areas. Fences, major road highways, railway lines or other barriers may separate the various parts. Nevertheless, they border each other and they are managed for long-term sustainable use of natural resources, although free movement of animals between the different parts is not possible (DEA, 2012). The establishment of transfrontier conservation areas is an exemplary process of partnerships. While the main players are the relevant governments and implementing agencies, donors and NGOs have also greatly contributed towards the creation of transfrontier parks (SANParks).

17 Regulation and management of parks are critical; parks need to uphold the laws and policy on biodiversity conservation and environmental protection.

\section{II}

\section{Regulation and management of national parks}

Regulation and management of parks are critical; parks need to uphold the laws and policy on biodiversity conservation and environmental protection. Most national parks, like other protected areas such as nature reserves and national heritage sites, fall within the laws and regulations of the (central) state. Their regulation is important as these areas are essential for the conservation of a country's biodiversity. Moreover, laws and regulation on biodiversity conservation ensure that the proper management of the parks are ensured.

According to the China Council for International Cooperation on Environment and Development (CCICED), there are several regulations on protected areas: the Nature Reserve Regulations, the Temporary Regulations for Scenic Landscape and Historical Site, and a Management Measures for Forest Parks. All nature reserves are established under the 1994 Regulations of the People's Republic of China on Nature Reserves which allow for only one management category, but nature reserves are established for a variety of purposes and at different levels of government: national and local (provincial. prefectural, county). Nature reserves are also assigned to one of three major types - wildlife protection, ecosystem protection or natural monument 
protection. Most reserves do, however, include elements of more than one type (CCICED, 2004). In terms of the operations of protected areas in China, local governments coordinate between government agencies (CCICED, 2004).

The regulation and management of national parks in South Africa has been institutionalised with one body. The Protected Areas Act 57 of 2003 gives SANParks its legal mandate, establishing that the conservation and sustainable use of biodiversity are important objectives to be achieved in national parks (2004). SANParks is managing all national parks while the Department of Environmental Affairs regulates them. On the one hand, South Africa has a protected areas act that sets out regulation for all protected areas (special nature reserves, national parks, nature reserves (including wilderness areas) and protected environments; world heritage sites; marine protected areas; specially protected forest areas, forest nature reserves and forest wilderness areas, and mountain catchment areas (Protected Areas Act 2003: 12).

Alongside the Protected Areas Act, the regulatory framework governing SANParks is the National Parks Act 57 of 1976 . This regulatory framework is used for all South African national parks. Under this Act, "the object of the constitution of a park is the establishment, preservation and study therein of wild animals, marine and plant life and objects of geological, archaeological, historical, ethnological, oceanographic, educational and other scientific interests and objects relating to the said life or the first mentioned objects or to events in or the history of the park, in such a manner that the area which constitutes the park shall, as far as may be and for the benefit and enjoyment of visitors, be retained in its natural state" (National Park Act 57 of 1976: $5)$.

11 SANParks has overall control in terms of what is allowed in the park, the number of people present in the parks as well as strict regulation regarding the activities of park employees.

SANParks has overall control in terms of what is allowed in the park, the number of people present in the parks as well as strict regulation regarding the activities of park employees. This ultimately is what ensures that limited threats are found to the natural landscape and the species that live in the park. The regulation is there to uphold that proper ecological conservation takes place with minimal disturbance from the pubic as well as other human activities. Moreover, it is noted that SANParks may make different regulations in respect of different parks. This makes sense as different parks in the different cities or provinces may be confronted with different experiences as well as threats to the park. Furthermore, some parks like Kruger National Park and Table Mountain National Park (TMNP), because they are popular tourists destinations, may further deal with more threats or pressure to the park as they receive more visitors thus different regulation may be necessary in that respect. TMNP in the Western Cape region of South Africa might be a specifically interesting case for mutual learning, as the park has to deal with an expanding and developing city around it as well as large numbers of tourists coming into the park. What is significant here, is the fact that Cape Town and other parts of the Western Cape has very rich biodiversity and ecological resources, especially in the form of fauna and flora, thus just like in parts of China, these particular species face increasing threats both natural and human-made.

This could be an important learning area for the Chinese where regulation is still in a nascent stage with regard to national parks. With a comparative approach, good 
practice can be identified. This is also of relevance for investors from China, who need to be elucidated about the regulation in South Africa and elsewhere on the continent.

\section{Management challenges of protected areas}

A variety of challenges for management of national parks were found and discussed by some sources. "Many scholars, both Chinese and foreign, have cited major problems with China's approach to conservation, particularly in nature reserves in western China. Some of these problems include, but are not limited to displacement and economic disenfranchisement of local people, 'paper park' syndrome, poor education of reserve managers, governmental oversight problems, lack of park funding and irresponsible development within protected areas" (Fritz, 2009: 8-9). One of the biggest challenges is funding. According to Su (2004 quoted in Yuan et al, 2008) $41,5 \%$ of the reserves in China are short of money to cover routine management activities. "Insufficient government funding for the operation of protected areas has resulted in increased revenue-raising activities within reserves, including tourism development and the harvesting of natural resources" (Xu and Melick, 2007 quoted in Yuan et al, 2008). Furthermore, there are often as many as ten different Chinese government ministries overseeing protected lands. Moreover, nature reserves are designated at the country, provincial and national levels, further complicating the administrative structure (Fritz, 2009: 13).

\section{Many scholars, both Chinese and foreign, have cited major problems with China's approach to conservation, particularly in nature reserves in western China. \\ 17}

According to Baiping et al, the "administration of world heritage sites and national parks by the central government is inappropriate" (2004: 205). There are too many different government departments involved in the administration of protected areas as well as national parks. The relevant government departments in charge of the parks, e.g. the Forestry Administration and the Ministry of Construction, were only loosely connected with the management of parks and heritage sites, with no clear aims and measures. Moreover, management of world heritage sites and parks were left to local governments which, in turn, rented them to tourist corporations (Baiping et al, 2004: 205). As a result, China continues to deal with the same administrative problems that it has dealt with in the past; administrative issues hinder the services that protected areas are supposed to be undertaking.

A further concern pointed out by Baiping et al (2004) is environmental awareness. Among the many causes of uncontrolled urbanisation in mountainous regions in China was due to the "lack of environmental awareness among tourists, authorities and scholars; and the lack of understanding of the purpose of protected areas," (Baiping et al, 2004: 206). Presently, although environmental awareness is growing among the Chinese, through the work of NGO's as well as the environmental policy being created, there is still a need for the education and understanding of the purpose of protected areas. A way of doing this has been through environmental education for students via the implementation of Green Schools (Sternang and Lundholm, 2011). China's Green School programme was initiated in 1996 and according to the same authors, there are now 16,000 schools across the country (2011: 4). "The model of Chinese Green Schools adheres to the spirit of fostering an environmentally friendly way of living" (Sternang and Lundholm, 2011). South Africa, for its part, has an established environmental education system; a comparison to China in this aspect can also be beneficial for mutual learning. 
According to Zinda (2011), by combining strong conservation rules with unified management and profitable tourism concerns, national parks are supposed to remedy pre-existing models' perceived defects. The author notes that the model TNC espouse has the following attributes:

"Tourism Underwrites Conservation: National park promoters contend that tourism activities can maximize revenue while minimizing impacts on conservation targets. They urge adopting forms of tourism that enable enjoyment of resources with minimal disturbance of conservation targets. In contrast with scenic areas, and in line with guidelines issued by the IUCN, tourism is subordinate to conservation goals" (Zinda, 2011: 6).

Some of these functions are mandated in existing regulations for nature reserves and scenic areas, but for the reasons cited earlier, implementation often suffers. As a result, according to Zinda (2011: 7), the goal of national park promoters is, by setting up an entirely new management model, to establish well-coordinated protected areas whose zoning and regulations accord with local conditions and whose management balances conservation and tourism objectives.

1 China's extremely rich biodiversity - in other words: its natural heritage - is under phenomenal threat, due to the steep pace of development, industrialisation and the consequences of the current development model.

\section{Conclusion}

China's extremely rich biodiversity - in other words: its natural heritage - is under phenomenal threat, due to the steep pace of development, industrialisation and the consequences of the current development model for air and water pollution, as well as a high population growth among other factors. Around the world in recent years, but more so in developing countries, there has been an increase in the loss of biodiversity, despite commitments of the world community enshrined in the Millennium Development Goals. Protected areas and their proper management are thus a crucial task for policy-makers globally. International good practice exists with regard to high standards such as for national parks, i.e. protected areas that have the primary objective of protecting biodiversity - and are a good example for mutual learning in China-Africa relations, too.

A system of contract parks might also be considered, as is done in South Africa. Contract parks were established in order to ensure that local communities, who inhabited the protected land first, were included in the management and development of the parks. Thus economic development that took place via the park (e.g. in zones that are open for tourism) could enrich the local communities of that area too. Contract parks might be an interesting model for China due to the number of people living in and around protected areas.

High protection standards do not preclude the additional aspects of national parks to provide education and recreation to the public; these goals are important in order to improve environmental awareness. Yet, the different purposes have to be managed and thus require a good regulation. While China has a body of regulation for protected areas including nature reserves, scenic landscapes and forest parks, this is not enough to ensure that the protected areas are properly managed. Moreover it is not enough that there is only provincial regulation for the national parks being developed in Yunnan province. China's future national parks will have to provide the necessary objectives and practices that protected areas need, namely: minimal human impact 
and disturbance in the protected areas, at least in core zones of the national parks. This is specifically important in countries where developmental pressure is high, but where nature-bound tourism figures have also skyrocketed. The latter might be a consequence of development pressure on citizens' daily lives, but it also provides an opportunity with regard to educative purposes.

\section{References}

Anonymous. (2008): China to build first pilot national park. [Online]. Available: http://www.chinese-embassy.org.za/eng/zgxw/t517305.htm [10 May 2011]

Baiping, Z., Shenguo, M., Ya, T., Fei, X., and Hongzhi, W. (2004): "Urbanisation and De-Urbanisation in Mountain Regions of China," Mountain Research and Development, Vol. 24, No. 3, 2004.

China Council for International Cooperation on Environment and Development. (2004): Task Force on Protected Areas (2003-2004). [Online]. Available: http://www.cciced.net/encciced/policyr/Taskforces/phase3/tfpa/200803/t20080304_14 5132.htm [2 February 2012]

DEA [Department for Environmental Affairs, RSA] (2012): The Gaza-KrugerGonarezhou Transfrontier Park. [Online]. Available: http://www.environment.gov.za/Documents/Documents/GreatLimpopoTP/background _GKG.htm [25 January 2012]

Dudley, N. (2008). Guidelines for Applying Protected Area Management Categories. Gland: IUCN.

Eagles, P. and McCool, S. (2004): Tourism in National Parks and Protected Areas: Planning and Management. Wallingford: CABI Publishing.

Fritz, K. (2009): National Parks in China: A New Model for Nature Conservation. SIT, Chinese Culture and Ethnic Minorities. Spring 2009.

Haomin, L. China Places We Protect: Pudacuo, China's First National Park China Establishes First National Park in Yunnan Province: Pudacuo National Park. [Online]. Available:

http://www.nature.org/ourinitiatives/regions/asiaandthepacific/china/placesweprotect/p udacuo-national-park.xml [ 21 October 2011]

Harkness, J. (1998): Recent Trends in Forestry and Conservation of Biodiversity in China, The China Quarterly. No. 156, 1998.

Jordan, S. (2010): "Network Public Management and the Challenge of Biodiversity Management in China" in Kaasiola, J. and Guo, S. ed,, China's Environmental Crisis: Domestic and Global Political Impacts and Responses. New York: Palgrave McMillan.

Mol, A. and Carter, N. (2007): "China's Environmental Governance in Transition" in Carter, N. and Mol, A. ed,, Environmental Governance in China. Oxon: Routledge

McBeath, J. and McBeath, J. (2006): Biodiversity Conservation in China: Policies and Practice, Journal of International Wildlife Law and Policy, No. 9, pp.293-317.

Reid H, Fig D, Magome H, Leader-Williams N. (2004): Co-management of Contractual National Parks in South Africa: Lessons from Australia. Conservat Soc 2:377-409.

Republic of South Africa. (1976): National Parks Act of 57 of 1976. [Online]. Available: http://www.mangaung.co.za/docs/National-Parks-Act.pdf [19 October 2011]

Republic of South Africa. (2004): National Environmental Management: Protected 
Areas Act 57 of 2003. [Online]. Available:

http://www.environment.gov.za/Services/documents.html [19 October 2011]

SANPArks. (2010): Biodiversity: Conservation In Times of Change. SANParks Scientific Services.

Sternang, L. and Lundholm, C. (2011): Climate Change and Costs: Investigating Students' Reasoning on Nature and Economic Development. Environmental Education Research, pp.1-11.

Yuan, J., Dai, L., and Wang, Q. (2008): State-led Ecotourism Development and Nature Conservation: a Case Study of the Changbai Mountain Biosphere Reserve, China, Ecology and Society, Vo. 13, No. 2, 2008.

Zinda, J. (2011): Hazards of collaboration: local state cooperation of a new protectedarea model in Southwest China, Society and Natural Res

Meryl Burgess is a research analyst at the Centre for Chinese Studies, working in the CCS' sustainability programme. She completed her Master's degree at Stellenbosch University in International Studies in 2012. 